\title{
Should all patients with sepsis receive anticoagulation? Yes
}

\author{
Ferhat Meziani $i^{1} 2^{*}$, Satoshi Gando ${ }^{3}$ and Jean-Louis Vincent ${ }^{4}$
}

(C) 2017 Springer-Verlag Berlin Heidelberg and ESICM

Sepsis is invariably associated with activation of blood coagulation owing to excessive thrombin formation, defective fibrinolysis and defective natural anticoagulants, resulting in fibrin deposits and ultimately in disseminated intravascular coagulation (DIC) [1]. Furthermore, as a result of microvascular thrombosis, sepsis-induced coagulopathy has been associated with multiple organ dysfunction syndrome and a poor prognosis [2]. This represents the basis for anticoagulation in all patients with sepsis.

The concept of immunothrombosis [3], highlighting that coagulation activation should be understood as an innate immune defence mechanism that may be essential, rather than a solely deleterious consequence of infection, should also be invoked in our PRO position. Indeed haemostasis could be interpreted as a first non-specific line of host defence and a regulated low-grade activation of thrombin generation could prove beneficial for surviving bacterial challenge. Thus, the recognition of "noxious haemostasis" or DIC remains a medical paradigm for critical care physicians.

Blood coagulation therefore may be a potentially interesting therapeutic target in sepsis and septic shock, to prevent or counteract excessive coagulation activation [4]. Significant reductions in the endogenous anticoagulants protein $\mathrm{C}$ and antithrombin correlate with DIC severity. Anticoagulant agents have largely been suggested to improve this prognosis. As a minimum, septic patients are at least at high risk of thrombosis, and preventive anticoagulation is usually required and could be achieved by heparin (Fig. 1).

\footnotetext{
*Correspondence: ferhat.meziani@chru-strasbourg.fr

${ }^{1}$ Service de Réanimation Médicale, Nouvel Hôpital Civil, Hôpitaux

Universitaires de Strasbourg, 1, Place de L'Hôpital, 67091 Strasbourg cedex, France

Full author information is available at the end of the article

For a contrasting viewpoint, please go to doi:10.1007/s00134-016-4607-x.
}

Experimental studies demonstrated the deleterious role of thrombin generation through the beneficial effects of anticoagulant (antithrombin, protein $\mathrm{C}$ and tissue factor pathway inhibitor-TFPI) on survival in endotoxic animal models [5].

Already heparin activates antithrombin leading to inactivation of thrombin, factor $\mathrm{Xa}$ and some proteases. Even though its exact role in vivo is still unclear, heparin could potentially be considered as an anticoagulant drug in sepsis. A meta-analysis by Wang et al. disclosed that heparin administration decreased mortality in septic patients [6]. Its short half-life and the availability of heparin antagonists facilitate its controlled use. The use of antithrombin seemed to be associated with increased survival in phase II studies, but this could not be confirmed in large phase III trials. Both the optimal dose and the duration of treatment, however, remain to be determined; Japanese trials and meta-analysis tend to highlight the efficacy and safety of moderate doses during sepsis [7]. Thrombomodulin acts on the thrombincatalysed conversion of protein $\mathrm{C}$ to activated protein $\mathrm{C}$, which has potential anticoagulant and cytoprotective effects [8]. In these different trials, the risk of bleeding complications would moreover be relatively low, suggesting that despite major coagulation disorders, anticoagulation of patients with sepsis-induced DIC would be safe.

Despite some useful properties, the same inhibitors were not demonstrated to be beneficial in clinical trials, and innovative treatments with activated protein C were withdrawn $[9,10]$, so that the latest Surviving Sepsis Campaign guidelines do not recommend any specific anticoagulant treatment [11]. Nevertheless, indirect response could be helpful: in some post hoc analyses of randomised clinical trials, it seems that less seriously ill patients (e.g. predicted mortality less than $25 \%$, APACHE II score less than 25 or SAPS II score less than 40) did not benefit from antithrombin, activated protein $\mathrm{C}$ or thrombomodulin therapy

\section{Springer}




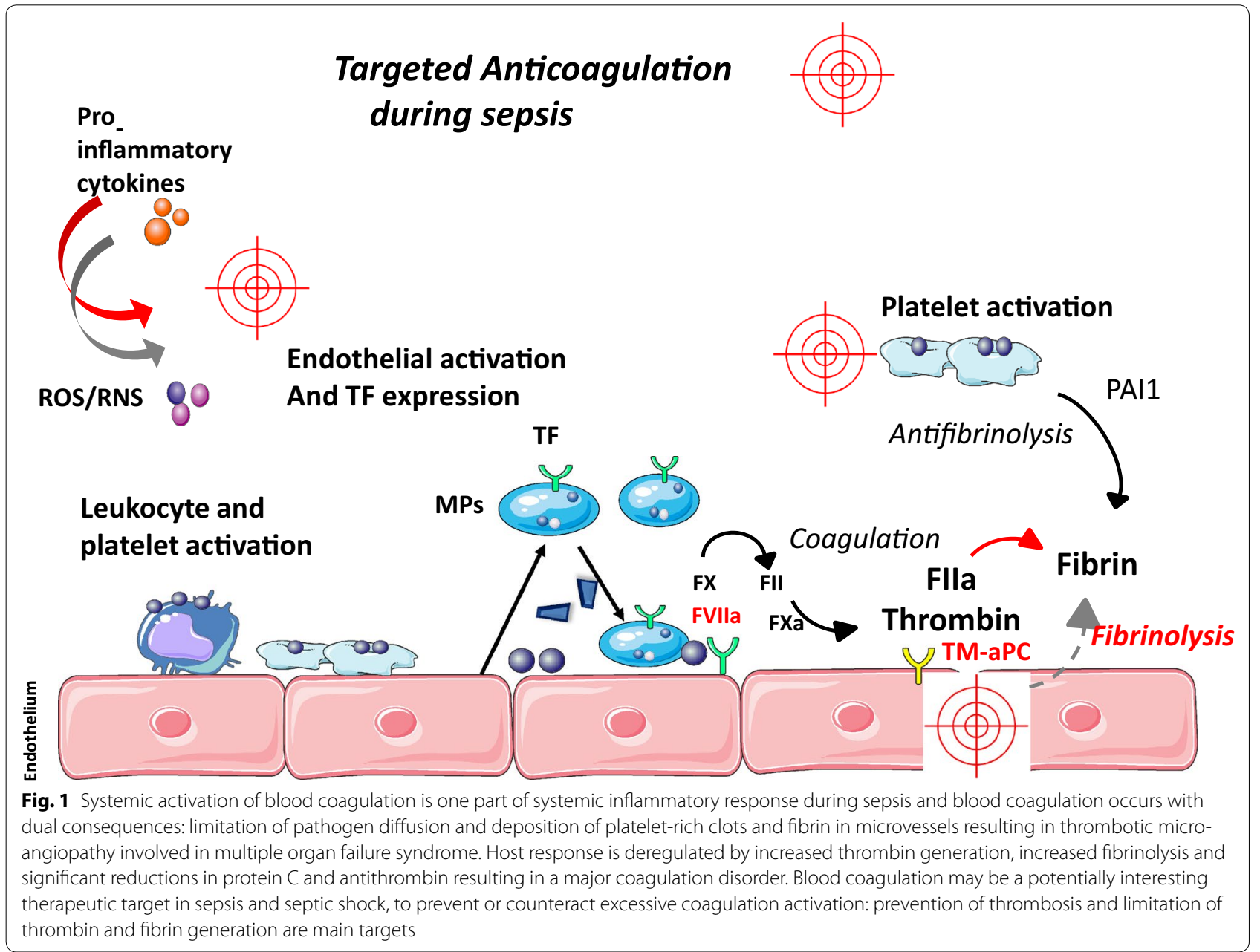

[12]. Activated protein $C$ drotrecogin alfa (activated) was shown to significantly decrease mortality in septic patients in the PROWESS study [13], and this was attributed to anticoagulant and cytoprotective effects, improving the microcirculation. Another placebocontrolled study, the Prowess-shock trial, was negative, but that study was conducted when the drug was on the market, so that the drug could still be reserved for more stratified patients. Indeed, post hoc analysis of the initial PROWESS trial evidenced that patients with DIC (according to modified ISTH 2001 "overt" criteria) seemed to benefit the most [14]. Heterozygous $\mathrm{FV}_{\text {Leiden }}$ carriers displayed improved survival in the PROWESS trial regardless of treatment allocation [13].

Nevertheless, the major drawback of the activated protein $\mathrm{C}$ trials was the lack of biomarker to identify the right patient population. In more general terms, the absence or inadequate stratification of septic patients on the basis of the coagulation activation status, leading to wrong (useless) allocation of anticoagulant treatments, could partly explain the negative results of trials. Indeed, despite several scoring systems [15], DIC is still poorly recognized. Moreover, anticoagulant treatments will disrupt a tight equilibrium between pathogen and adaptive host response. Thrombomodulin, which combines anticoagulant and anti-inflammatory effects, represents another therapeutic option [4]. Interestingly, in the different clinical trials the risk of bleeding complications generally seemed to be relatively low, suggesting that despite major coagulation disorders, anticoagulation of patients with sepsis is in general quite safe. Few trials have so far allocated anticoagulant treatments to a selected subset of septic patients on the basis of coagulopathy criteria. This is the case now for the development of thrombomodulin. Following encouraging results of a phase II trial, a larger study is underway in which septic patients are enrolled when they have a low platelet count and a prolonged INR. This 800 -patient trial is in its second half [16]. 
If several trials have then suggested beneficial effects in the subgroup of patients with sepsis-induced DIC, the ideal anticoagulant has not been identified yet and further clinical trials are needed before a specific anticoagulant substance could be recommended in specific subgroups of patients. All anticoagulants are likely not to have the same properties, some of them being additionally attributed cytoprotective effects. Clearly biomarkers are needed as diagnostic and prognostic markers of early DIC. Delabranche et al. [17] recently demonstrated that both endothelial- and leukocyte-derived microparticles reflecting endothelial and leukocyte activation are relevant biomarkers of sepsis-induced DIC during septic shock and might help early diagnosis and stratification of the patients for future therapeutic strategies.

\section{Author details}

1 Service de Réanimation Médicale, Nouvel Hôpital Civil, Hôpitaux Universitaires de Strasbourg, 1, Place de L'Hôpital, 67091 Strasbourg cedex, France. ${ }^{2}$ EA 7293, Fédération de Médecine Translationnelle de Strasbourg (FMTS), Faculté de médecine, Université de Strasbourg, Strasbourg, France. ${ }^{3}$ Division of Acute and Critical Care Medicine, Department of Anesthesiology and Critical Care Medicine, Hokkaido University Graduate School of Medicine, Sapporo, Japan. ${ }^{4}$ Department of Intensive Care, Erasme Hospital, Université libre de Bruxelles, Brussels, Belgium.
}

\section{Compliance with ethical standards}

\section{Conflicts of interest}

The authors have no conflict of interest relevant to this article to declare.

Received: 25 October 2016 Accepted: 1 November 2016

Published online: 13 February 2017

\section{References}

1. Gando S, Meziani F, Levi M (2016) What's new in the diagnostic criteria of disseminated intravascular coagulation? Intensive Care Med 42(6):1062-1064

2. Fourrier $F(2012)$ Severe sepsis, coagulation, and fibrinolysis: dead end or one way? Crit Care Med 40:2704-2708

3. Engelmann B, Massberg S (2013) Thrombosis as an intravascular effector of innate immunity. Nat Rev Immunol 13:34-45

4. Levi M (2015) Recombinant soluble thrombomodulin: coagulation takes another chance to reduce sepsis mortality. J Thromb Haemost 13:505-507

5. Fourrier F, Jourdain M, Tournois A, Caron C, Goudemand J, Chopin C (1995) Coagulation inhibitor substitution during sepsis. Intensive Care Med 21(Suppl 2):S264-S268

6. Wang C, Chi C, Guo L, Wang X, Guo L, Sun J, Sun B, Liu S, Chang X, Li E (2014) Heparin therapy reduces 28-day mortality in adult severe sepsis patients: a systematic review and meta-analysis. Crit Care 18(5):563

7. Gando S, Saitoh D, Ishikura H, Ueyama M, Otomo Y, Oda S, Kushimoto S, Tanjoh K, Mayumi T, Ikeda T, Iba T, Eguchi Y, Okamoto K, Ogura H, Koseki K,
Sakamoto Y, Takayama Y, Shirai K, Takasu O, Inoue Y, Mashiko K, Tsubota T, Endo S, Japanese Association for Acute Medicine Disseminated Intravascular Coagulation Study Group for the JDICAT (2013) A randomized, controlled, multicenter trial of the effects of antithrombin on disseminated intravascular coagulation in patients with sepsis. Crit Care 17(6):R297

8. Yamakawa K, Aihara M, Ogura H, Yuhara H, Hamasaki T, Shimazu T (2015) Recombinant human soluble thrombomodulin in severe sepsis: a systematic review and meta-analysis. J Thromb Haemost 13(4):508-519

9. Abraham E, Reinhart K, Opal S, Demeyer I, Doig C, Rodriguez AL, Beale R, Svoboda P, Laterre PF, Simon S, Light B, Spapen H, Stone J, Seibert A, Peckelsen C, De Deyne C, Postier R, Pettila V, Artigas A, Percell SR, Shu V, Zwingelstein C, Tobias J, Poole L, Stolzenbach JC, Creasey AA, Group OTS (2003) Efficacy and safety of tifacogin (recombinant tissue factor pathway inhibitor) in severe sepsis: a randomized controlled trial. JAMA 290:238-247

10. Ranieri VM, Thompson BT, Barie PS, Dhainaut JF, Douglas IS, Finfer S, Gardlund B, Marshall JC, Rhodes A, Artigas A, Payen D, Tenhunen J, Al-Khalidi HR, Thompson V, Janes J, Macias WL, Vangerow B, Williams MD, PROWESSSHOCK Study Group (2012) Drotrecogin alfa (activated) in adults with septic shock. N Engl J Med 366(22):2055-2064

11. Dellinger RP, Levy MM, Rhodes A, Annane D, Gerlach H, Opal SM, Sevransky JE, Sprung CL, Douglas IS, Jaeschke R, Osborn TM, Nunnally ME, Townsend SR, Reinhart K, Kleinpell RM, Angus DC, Deutschman CS, Machado FR, Rubenfeld GD, Webb SA, Beale RJ, Vincent JL, Moreno R, Surviving Sepsis Campaign Guidelines Committee including the Pediatric Subgroup (2013) Surviving Sepsis Campaign: international guidelines for management of severe sepsis and septic shock: 2012. Crit Care Med 41:580-637

12. Umemura Y, Yamakawa K (2016) Efficacy and safety of anticoagulant therapy in three specific populations with sepsis: a meta-analysis of randomized controlled trials. J Thromb Haemost 14(3):518-530

13. Bernard GR, Vincent JL, Laterre PF, LaRosa SP, Dhainaut JF, LopezRodriguez A, Steingrub JS, Garber GE, Helterbrand JD, Ely EW, Fisher C J Jr, Recombinant human protein CWorldwide Evaluation in Severe Sepsis (PROWESS) study group (2001) Efficacy and safety of recombinant human activated protein C for severe sepsis. N Engl J Med 344(10):699-709

14. Dhainaut JF, Yan SB, Joyce DE, Pettila V, Basson B, Brandt JT, Sundin DP, Levi M (2004) Treatment effects of drotrecogin alfa (activated) in patients with severe sepsis with or without overt disseminated intravascular coagulation. J Thromb Haemost 2(11):1924-1933

15. Iba T, Di Nisio M, Thachil J, Wada H, Asakura H, Sato K, Kitamura N, Saitoh D (2016) Revision of the Japanese Association for Acute Medicine (JAAM) disseminated intravascular coagulation (DIC) diagnostic criteria using antithrombin activity. Crit Care 20:287

16. Vincent JL, Ramesh MK, Ernest D, LaRosa SP, Pachl J, Aikawa N, Hoste E, Levy H, Hirman J, Levi M, Daga M, Kutsogiannis DJ, Crowther M, Bernard GR, Devriendt J, Puigserver JV, Blanzaco DU, Esmon CT, Parrillo JE, Guzzi L, Henderson SJ, Pothirat C, Mehta P, Fareed J, Talwar D, Tsuruta K, Gorelick KJ, Osawa Y, Kaul I (2013) A randomized, double-blind, placebo-controlled, phase $2 \mathrm{~b}$ study to evaluate the safety and efficacy of recombinant human soluble thrombomodulin, ART-123, in patients with sepsis and suspected disseminated intravascular coagulation. Crit Care Med 41:2069-2079

17. Delabranche $X$, Quenot J, Lavigne T, Mercier E, François B, Severac F, Grunebaum L, Mehdi M, Zobairi F, Toti F, Meziani F, Boisramé-Helms J, Clinical Research in Intensive Care and Sepsis Network (2016) Early detection of disseminated intravascular coagulation during septic shock: a multicentre prospective study. Crit Care Med 44:e930-e939 